Sverre Pettersen was a laboratory researcher in the field of coronary heart diseases before he in 1992 became an associate professor at Akershus University College, Lillestrøm, where he teaches biological sciences for nursing students, as well as being supervisor for students attending the college's master programme. He has also taught biology, chemistry and mathematics in Norwegian upper secondary school for 12 years. From the year of 2000 he has followed the doctoral programme in science education at the Institute of teacher training and school development, University of Oslo. In his present research project, he mainly explores the "status" of science and scientific knowledge among students and teachers of Norwegian health sciences.

\title{
Critical Thinking in Norwegian Upper Secondary Biology Education: The Cases of Complementary-Alternative- Medicine and Health Claims in the Media
}

\begin{abstract}
By definition, complementary alternative medicine (CAM) treatments are not scientifically proven. Scientific deficient health claiming news seems to flourish in the media. The aims of this questionnaire study was to explore: (1) attitudes towards CAM among $3^{\text {rd }}$ year students of the health sciences in Norway, who either have immersed themselves in the $2^{\text {nd }}$ and $3^{\text {rd }}$ year upper secondary biology courses, or taken the $1^{\text {st }}$ year compulsory natural science course, exclusively, and (2) these students' skills in requesting for scientific information in highly deficient health news briefs. There were no significant differences in the frequencies of positive attitude towards the use of CAM treatments between the two health sciences student categories, and most students in both categories "failed" in the test set out to measure their skills in requesting for scientific information in four highly scientific deficient health news briefs. The results suggest that teaching of the Norwegian upper secondary biology courses does probably not contribute extensively to pupils' development of scepticism towards CAM, and skills in evaluating health claims, scientifically.
\end{abstract}

\section{INTRODUCTION}

By definition, most complementary-alternative medicine (CAM) therapies are not scientifically proven (Cassileth, 1999). The epistemologies of conventional medicine treatments and CAM are largely different; what is evidence of a claim, what counts as a warrant for that evidence, and what are the standards of validity, are all epistemology linked questions (Sampson, 2001; Pallas, 2001). Despite the absence of scientific evidence, the interest in CAM in the lay public of Western societies has increased during the last twenty years, and younger people seem to be more positive towards the use of CAM than the elderly (Astin, 1998).

There are possibly large differences between the standards of validity used to evaluate CAM effects by their advocates, and the scientific standards featuring the knowledge presented in any science textbook of upper secondary school education. Epistemic understanding refers to the set of ideas that we would like pupils and students to understand and be able to appropriate as they 
engage in or think about science (Kuhn, 2001). Intrinsic to epistemic understanding is knowledge of the criteria by which scientific knowledge is evaluated. Such criteria include plausible causal mechanisms, parsimony, consistency with observed data, and consistency with current theories (Lederman, 1992).

Pupils' and students' degree of sucessfulness in performing scientific evaluation of health claims (for example claims of CAM effects) probably depends on their scientific reasoning abilities (Steussy, 1984) and critical thinking skills (Paul, 1995; Korpan, Bisanz, Bisanz \& Henderson, 1997). Scientific reasoning is "used to denote consistent, logical thought patterns which are employed during the process of scientific inquiry that enable individuals to propose relationships between observed phenomena; to design experiments which test hypotheses concerning the proposed relationships; to determine all possible alternatives and outcomes; to consider probabilities of occurrences; to predict logical consequences; to weight evidence or proof; and to use a number of instances to justify a particular conclusion" (Steussy, 1984, p. 2). The acquirement of such personal skills is probably a main aim of science education. Several definitions of the critical thinking concept exist. According to Watson and Glaser (1980), critical thinking includes attitudes of inquiry that involve an ability to recognize the existence of problems and an acceptance of the general need for evidence in support of what is asserted to be true. In my opinion, individuals' epstemic understanding and scientific reasoning ability are associated with (or might be suppositions to) their critical thinking skills. According to Paul (1995), the learning of critical thinking with its knowledge assumptions should be a concern to upper secondary school teachers, who are involved in qualifying pupils for higher education.

In the syllabus of the $1^{\text {st }}$ year compulsory natural science course (1NA) of upper secondary school in Norway, the following statement and goal probably reflects that pupils should learn to be "critical:" "Scientific research methods might contribute to develop pupils' creative and critical skills," (KUF, 1994, p. 272)...., and [the pupose of the 1NA training is] "to disseminate knowledge of biology, physics, and chemistry for enabling pupils to understand and evaluate information about health, technology, environment, and other science topics which are part of their every-day life, critically" (KUF, 1994, p. 274).

Many students of nursing, physiotherapy, social educator, and radiography have the 1NA course as their only upper secondary science qualification for these college studies (Pettersen \& Solberg, 2003). That is probably because immersion in upper secondary school science during the pupils' $2^{\text {nd }}$ and $3^{\text {rd }}$ year is not a compulsory entrance requirement for most university college health science educations in Norway (ODIN, 2005a; Studiehåndboka, 2004). However, when the health science students actually have immersed themselves in upper secondary school science, it seems to be most frequently in the $2^{\text {nd }}$ and $3^{\text {rd }}$ year biology courses (2BI and 3BI, respectively) (Pettersen \& Solberg, 2003). The following Norwegian 2BI and 3BI syllabi statements probably reflect the need for pupils' knowledge of the "nature of science" as an ingredient of their epistemic understanding: "One characteristic feature of biology is that accepted biological knowledge is constantly being challenged by new research findings. A historical perspective on the subject is therefore important, because the established truth has always changed with the acquisition of further knowledge" (ODIN, 2005b, p. 2). Considering that the epistemologies of CAM treatments possibly represent a real challenge to the "established truth" about human physiology, illness evolvement and curing of diseases (Sampson, 2001), one might question whether the pupils who have completed the two advanced biology courses $(2 \mathrm{BI}+3 \mathrm{BI})$ of Norwegian upper secondary education have different attitudes towards the use of non-scientifically proven CAM treatments than the 1NA trained pupils?

Scientific deficient health claiming news seems to flourish in the media (Korpan et al., 1997; Pettersen, 2005a). Science education researchers have shown that many pupils and students fail to assess the reliability of science related information to which they are exposed in everyday life 
(Norris \& Phillips, 1994; Korpan et al., 1997; Pettersen \& Solberg, 2003). Although being practical by nature, the cookbook-type exercises and pre-described protocols for laboratory work that probably feature upper secondary biology courses, might still be considered as content-knowledge in biology (Favero, 1998). It has been showed that when pupils do school science, (e.g. laboratory and field work) they do not necessary understand or pick up the "tacit messages" from these activities (e.g. reflections of the contexts of science research, the scientific standards of validity, and the applicability and limitations of science methodology) (Kolstø, 2001; Kind, 2003). These individuals could probably be easily deceived and defrauded by pseudoscience, which is quite commonly observed in theories of CAM effects (Sampson, 2001; Pettersen, 2005b). Studies have shown that media coverage of health issues is many people's main source of body knowledge and health information. (Bell, 1998; Schwitzer et al. 2005).

This article has two research questions: (1) Are there any differences in attitudes towards CAM between $3^{\text {rd }}$ year students of the health sciences who either have immersed themselves in the upper secondary biology courses $(2 \mathrm{BI}+3 \mathrm{BI})$, or taken the 1NA course, exclusively? (2) Are 2BI+3BI immersed health science students better skilled in requesting for scientific information in highly deficient health news briefs than health science students who have taken the 1NA course as their only upper secondary science education?

\section{MATERIALS AND METHODS}

The $1^{\text {st }}$ year natural science course, abbreviated 1NA, is compulsory to all pupils of upper secondary education, while the $2^{\text {nd }}$ and $3^{\text {rd }}$ year science courses are not. The 1 NA course is taught 5 periods a week, focusing on concepts and principles of biology, chemistry, physics, and geology, which have not a high degree of difficulty. Pupils can either attend the $2^{\text {nd }}$ and $3^{\text {rd }}$ year courses either separately, or in combinations. The $3^{\text {rd }}$ year science courses are more advanced than the $2^{\text {nd }}$ year courses, and most pupils take the $2^{\text {nd }}$ year courses before they take the $3^{\text {rd }}$ year courses.

The 2BI and 3BI courses are taught 3 and 5 periods a week, respectively. The courses cover a broad range of biology subjects, including biochemistry, human physiology and genetics (ODIN, 2005b). However, both pupils and teachers have reported that topics of the 2BI and 3BI syllabi are comprehensive and advanced, and it is barely manageable to accomplish all what is demanded by the applied curricula (BUN, 2004, unpublished results).

\section{Health science student questionnaire}

\section{Attitudes towards CAM}

The students were asked to respond to Likert scale-valued $(1=$ strongly negative; $5=$ strongly positive) statements about their attitudes towards the use of 15 common CAM treatments (Poleszynski, 1999). If students were not familiar with the CAM treatments in question, an "I don't know" answer alternative was provided.

For the statistical analysis of possible significant difference in frequencies of "CAM-subscribers" across the two student groups and CAM treatments, the numbers of "strongly positive" and "positive" answers were collapsed and recoded (keeping the label "positive" for convenience).

\section{News brief assessment test}

Four fictitious health news briefs were created and included in the student questionnaire (for details see Solberg, 2002; Pettersen \& Solberg, 2003). Deliberately, these four fictitious news briefs did not contain any scientific information. However, they all reflected a typical content and format standard of 88 real health claiming news brief found in each of two major Norwegian newspapers during 1999 and 2000 (Solberg, 2002). The four news briefs had identical structure and the same scientific topic code deficiencies, which should evoke the students' skills in requesting for ade- 
quate descriptions about the following six topic codes: social context, theory, method, data/statistics, related research, and relevance of the health news reported (Korpan et al., 1997; Pettersen \& Solberg, 2003).

The two questions following each of these four fictitious news briefs were:

-How likely do you think it is that the conclusion (in bold letters) is true?

-Suppose that the conclusion (in bold letters) is very important to you and that you must determine whether it is true. What additional pieces of information, if any, would you like to have about the researchers' report to decide whether this conclusion is correct? Please list each point you make separately:

In the first question, five-point Likert scaled answer alternatives were available ( $1=$ very unlikely; $5=$ very likely), while in the second question, seven numbered places for requests were provided for each news brief. The coder's task was to reach each request and assign the scientific topic code that most clearly represented the student's request for information. Three coders independently scored the data for the pilot and this present study. The aggreement of their judgment across the topics was $97 \%$. Figure 1 shows one of the four fictitious news briefs applied in the scientific evaluation test (Solberg, 2002; Pettersen \& Solberg, 2003).

Analysis of the peer reviews and pilot studies caused only a few linguistic changes of the health science student questionnaire.

\title{
THERAPEUTIC TOUCH RELIEVES PAIN
}

\section{Using Therapeutic Touch is an important treatment of migraine.}

\author{
British scientists have reported that people suffering from migraine receiving the Therapeutic \\ Touch treatment experienced a noticeable pain relief. Intensive and durational headache are \\ problematic for these people. The Migraine Association has hailed this important research \\ finding.
}

Figure 1. One of the four fictitious, scientific topic code-deficient news briefs.

\section{Samples, statistics and response rate}

All Norwegian university colleges of nursing, physiotherapy, social educator, and radiography were invited to participate in a questionnaire study. The eligible number of nursing colleges was 31, of physiotherapy: 4 , of social educator: 8 , and of radiography: 4 . The invitees were students in their final $3^{\text {rd }}$ year of education. 16, 3, 5 and 2 of these eligible colleges responded positive to the invitation, respectively. A paper copy of the questionnaire was sent by post to each student's home address, and the completed form should be returned to sender similarly (a postage paid envelop was included in the dispatch). Information of the research project aims and questionnaire guidelines were included in the questionnaire dispatch. All returned questionnaires were treated anonymously.

The number of items on the health science student questionnaire was 254, and many statements and questions were meant to answer other research questions (Pettersen \& Solberg, 2003; Pettersen, 2004; Pettersen, 2005b). For answering the research questions of this article, the participating health science students of the four educations were considered a uniform group. Then, two new student categories were constructed: (1) Students who have not immersed themselves in any of the eligible $2^{\text {nd }}$ and $3^{\text {rd }}$ year science courses of upper secondary school; they have only taken the $1^{\text {st }}$ year compulsory natural science course (1NA), and (2) Students who have taken the $2^{\text {nd }}$ and $3^{\text {rd }}$ year biology courses $(2 \mathrm{BI}+3 \mathrm{BI})$, and not attended any other upper secondary science courses, as chemistry $(2 \mathrm{KJ} / 3 \mathrm{KJ})$, or physics $(2 \mathrm{FY} / 3 \mathrm{FY})$ during their time in school. 
The number of participating $3^{\text {rd }}$ year students of nursing was $n=317$; physiotherapy, $n=63$; social educator, $n=59$ and of radiography, $n=34$, making a total of $N=473$ health science student participants. This corresponds to a response rate of 20-33\%. About $67 \%(\mathrm{~N}=327)$ of the total number of responding health science students had the 1NA course as their only upper secondary science training, while $17 \%(\mathrm{~N}=80)$ were immersed in the $2 \mathrm{BI}$ and $3 \mathrm{BI}$ courses.

The data were statistically analysed using SPSS for Windows, version 11.0. Chi-square analysis were used to explore possible differences in frequencies of "positive" attitude towards each of the the 15 CAM treatments between the two student groups. Mann-Whitney-U tests were used to explore possible differences between the two groups' "belief" in the health news brief conclusions, as well as in the numbers of scientific topic codes requested in these briefs. The $p$-value level of significance was set at 0.05 . However, because of the none-probabilistic sampling of the students, and the low response rate, accordingly, extensive use of sample statistics has been avoided.

\section{RESULTS}

Table 1 shows the 2BI+3BI-immersed and the 1NA trained health science students' frequencies of positive attitude towards 15 CAM treatments.

Most students in both groups were positive towards seven of the 15 CAM treatments. Even though more 1NA trained students than 2BI+3BI-immersed students were were positive towards Herb medicine, Kinesiology, Hydrotherapy of the colon, Healing, and Mega-vitamin doses, there were no significant differences between these frequencies across the two student groups. Apparently, more 2BI+3BI-immersed students than 1NA trained students were positive towards Prayer, faith healing, Osteopathy, Light therapy, and Magnet therapy.

Table 1. The frequencies of $1 N A$ trained students' and 2BI+3BI-immersed students' positive attitude towards each of 15 CAM treatments. Chi-square analysis was used to explore possible significant differences between student groups and treatments.

\begin{tabular}{|c|c|c|c|}
\hline \multirow[t]{2}{*}{ CAM } & $\begin{array}{c}\text { 1NA } \\
(\mathrm{N}=327)\end{array}$ & $\begin{array}{l}2 \mathrm{BI}+3 \mathrm{BI} \\
(\mathrm{N}=80)\end{array}$ & \multirow[t]{2}{*}{$\begin{array}{l}\text { Level of sign } \\
\quad(p \text {-value })\end{array}$} \\
\hline & $\%$ positive & $\%$ positive & \\
\hline Acupuncture & 90 & 89 & - \\
\hline Zone therapy & 76 & 75 & - \\
\hline Aroma therapy & 66 & 61 & - \\
\hline Therapeutic touch & 64 & 65 & - \\
\hline Light therapy & 62 & 68 & - \\
\hline Herb medicine & 59 & 49 & - \\
\hline Homeopathy & 58 & 58 & - \\
\hline Kinesiology & 28 & 19 & - \\
\hline Hydro therapy of the colon & 27 & 19 & - \\
\hline Healing & 21 & 16 & - \\
\hline Colour therapy & 18 & 18 & - \\
\hline Magnet therapy & 16 & 18 & - \\
\hline Prayer, faith healing & 13 & 21 & $<0.05$ \\
\hline Mega-vitamin doses & 13 & 11 & - \\
\hline Osteopathy & 12 & 19 & - \\
\hline
\end{tabular}


Table 2. Students' mean "belief" in each of the four health news brief conclusions (Mann-Whitney U-tests).

\begin{tabular}{lcccc}
\hline News Briefs & $\begin{array}{c}\text { Science } \\
\text { course } \\
\text { completed }\end{array}$ & N & $\begin{array}{c}\text { "How likely?" } \\
\text { Mean (S.D). }\end{array}$ & $\begin{array}{c}\text { Level of } \\
\text { sign. } \\
(p \text {-value })\end{array}$ \\
\hline Drug against smoking & 1NA & 327 & $3.26(0.89)$ & 0.027 \\
& 2BI+3BI & 80 & $3.01(0.90)$ & \\
\hline $\begin{array}{l}\text { High voltage power } \\
\text { lines cause leukemia }\end{array}$ & 1NA & 327 & $3.58(0.84)$ & - \\
\hline $\begin{array}{l}\text { Therapeutic touch } \\
\text { relieves pain }\end{array}$ & 1NA & 327 & $3.87(0.90)$ & - \\
\hline $\begin{array}{l}\text { Physical training cuts } \\
\text { back on medication }\end{array}$ & 2BI+3BI & 80 & $3.90(0.68)$ & - \\
\hline
\end{tabular}

Table 2 shows how likely the two student groups thought that the four health news brief conclusions were "true."

Most students in both categories expressed that the conclusions in all four news briefs were "true" (mean values $>3.00$ ), despite these briefs' scientific content deficiencies.

Table 3 shows the mean numbers of scientific topic codes requested by the two student groups in the four fictitious health news briefs.

Health science students in both categories requested on average about one scientific topic code (of the optimum of six codes) in the four news briefs. Although, the 2BI+3BI immersed students requested more codes than the 1NA trained students, there were no significant differences between the mean values of the two groups.

Table 3. The mean numbers of scientific topic codes requested in four fictitious health news briefs (Mann-Whitney U-tests).

\begin{tabular}{|c|c|c|c|c|}
\hline News Briefs & $\begin{array}{c}\text { Science } \\
\text { course } \\
\text { completed }\end{array}$ & $\mathbf{N}$ & $\begin{array}{c}\text { Requests } \\
\text { Mean (S.D). }\end{array}$ & $\begin{array}{c}\text { Level of } \\
\text { sign. } \\
(p \text {-value })\end{array}$ \\
\hline \multirow[t]{2}{*}{ Drug against smoking } & 1NA & 325 & $1.22(1.13)$ & \\
\hline & $2 \mathrm{BI}+3 \mathrm{BI}$ & 79 & $1.27(1.16)$ & \\
\hline \multirow{2}{*}{$\begin{array}{l}\text { High voltage power } \\
\text { lines cause leukemia }\end{array}$} & 1NA & 326 & $1.11(1.05)$ & \multirow{2}{*}{ - } \\
\hline & $2 \mathrm{BI}+3 \mathrm{BI}$ & 80 & $1.21(1.16)$ & \\
\hline \multirow{2}{*}{$\begin{array}{l}\text { Therapeutic touch } \\
\text { relieves pain }\end{array}$} & $1 \mathrm{NA}$ & 326 & $0.90(1.01)$ & \multirow[b]{2}{*}{ - } \\
\hline & $2 \mathrm{BI}+3 \mathrm{BI}$ & 78 & $1.08(1,00)$ & \\
\hline \multirow{2}{*}{$\begin{array}{l}\text { Physical training cuts } \\
\text { back on medication }\end{array}$} & 1NA & 326 & $0.80(0.94)$ & \multirow{2}{*}{ - } \\
\hline & $2 \mathrm{BI}+3 \mathrm{BI}$ & 80 & $0.88(0.97)$ & \\
\hline
\end{tabular}




\section{Discussion}

\section{Students' attitudes towards CAM}

It was not surprising that most of the responding health science students had a positive attitude towards CAM; previous research has shown that young people, students and professionals engaged in typical female dominated health care practices largely subscribes to CAM (Astin, 1998; Risberg \& Kolstad, 2003). The numbers of female and male responding 2BI+3BI students of this study were 59 and 21, which is in accordance with national statistics ascertaining that these upper secondary school biology courses have a female predominance (UFD, 2005). However, there was no essential gender difference in the 2BI+3BI student respondents' attitudes towards CAM (data not shown).

Cobern and Aikenhead (1998) and Sjøberg (2000) claim that school science mediates a scientific worldview, implicitly. It is probably not preposterous to assume that pupils who do not want to immerse themselves in any $2^{\text {nd }}$ and $3^{\text {rd }}$ year upper secondary school science courses might hold a weaker "scientistic attitude" than the ones who do, and, therefore, they could initially be the most open to accept CAM. However, since most of the responding students who had taken the biology courses $2 \mathrm{BI}+3 \mathrm{BI}$ nevertheless did express a positive attitude towards $\mathrm{CAM}$, it might indicate that: (1) the pupils who attend the upper secondary school biology courses have a positive attitude towards CAM, (2) they do probably not hold a strong scientistic attitude, (3) the epistemology of CAM is not critically discussed in the teaching of 2BI and 3BI courses for exercising the pupils' scientific reasoning abilities and critical thinking skills, and (4) although CAM could have been critically discussed in these courses, the pupils have still retained their positive attitude towards CAM during upper secondary education - and during health science college education, as well. There might be a "supportive climate" for teaching of CAM in Norwegian health science educations at present (Pettersen \& Bye, 2005).

The epistemologies, and what counts as reliable knowledge in the fields of biomedicine and CAM are largely different (Sampson, 2001; Holton, 1992), of which the 2BI+3BI immersed students should possibly know about through teaching of these courses. Their positive attitude towards CAM might, however, been obtained in spite of this internalized knowledge and their skills in scientific reasoning and critical thinking: When people seek treatments for chronic illnesses and diseases, the scientific documentation of these treatment effects seems to be of secondary importance; their belief in the healing effects of the treatments is superior (Astin, 1998). Apparently, users of CAM treatments are found among those who have higher degrees in science (ibid), indicating that it is probably not appropriate to link individuals' positive attitude towards the use of CAM treatments simple to their lack of scientific reasoning abilities and critical thinking skills. However, research has shown that persons' attraction towards CAM could be related to their adherence of post-modern philosophy, which might involve adoption to certain values, worldview and beliefs, such as emphasis on nature and natural remedies, anti-science sentiments, holistic view of health, and rejection of scientific authority (Siahpush, 1999; O'Callaghan \& Jordan, 2003). Pettersen \& Olsen (2005) have recently demonstrated that Norwegian health science students' positive attitude towards CAM correlated positively with their beliefs in paranormal phenomena, and that reliable knowledge is obtained by intuition/spiritual experiences. Paranormal phenomena could be defined as events that violate the boundaries of current scientific beliefs (Goode, 2002). Explanation theories to both paranormal phenomena and CAM effects are often highly pseudoscientific, and should preferably be a concern to science education (Martin, 1994; Sampson, 2001). The study of Pettersen and Olsen (2005) also showed that health science students' less scientific worldview (operationalized by several attitude measuring constructs) predicted their positive attitude towards CAM. 
Although the explanation to the explored 1NA and 2BI+3BI students' positive attitude towards (or belief in) CAM might be complex, this article's results, viewed in the light of the referred research findings, probably suggest that critical discussions of CAM and science epistemologies should more emphasized in these upper secondary science courses. A beneficial outcome of the discussions might be pupils' knowledge of the "nature of science" (Lederman, 1992).

\section{Critical evaluation of highly scientific deficient health news briefs}

The 2BI+3BI-immersed students were not significantly more sceptical towards the conclusions in the four highly scientific deficient health news briefs than the 1NA trained students. In fact, most students in both categories considered that the conclusions were "true." Why people have a tendency to uncritically hail the conclusions of most newspaper science research reports (Korpan et al., 1997) is interesting, and might be subject to further research. For many people, phrases like "the newspaper says," and "scientists have reported" seem to be a guarantee for the validity of the presented issues (Norris \& Phillips, 1994). On the other hand, it has been shown that people might have tendency to accept conclusions because they are believable rather than because they are logically valid (Torrens, 1999), and young people might have difficulty differentiating explanation of why a claim makes sense and evidence that the claim is "true" (Kuhn, 2001).

Although the four fictitious news brief topics were plausible, the framework of the research results was very insufficiently described. The students were asked to add more scientific information in the briefs if thought necessary. In science publications, conclusions are closely linked to a detailed description of (at least) theory and research methods. Considering that the presentation of the health news briefs conclusions had no reference to methodology, one could expect that the 2BI+3BI immersed students, especially, showed more vigilance on these matters - of which they did not. If teaching of the validity standards of scientific health claims is not emphasized, pupils might consider any health claim drawing upon some biological science knowledge as reliable or "true." On the other hand, some pupils might consider any science textbook-knowledge more objective than it ought to be - and "true" in an absolute sense. Many current health issues which are highlighted in the press are often typical examples of "science-in-the-making" (Millar \& Driver, 1987; Pettersen, 2005a) or frontier science (Bauer, 1994). Pupils might, therefore, be poorly prepared when media print stories about scientists who give conflicting answers to the same research questions (Bringle \& Gaskell, 1994; Kolstø, 2001).

The 2BI+3BI-immersed students did not request for more scientific topic codes in the four news briefs than the 1NA-students. Both student categories requested on average about one scientific topic code in each of the four briefs (of an optimum of six topic codes). This article's results probably suggest that most of the responding students of both categories have not learned what to request for - either during upper secondary education, or during their respective health science college education. International science education research has shown that many pupils and students find it difficult to evaluate media reports of science research, scientifically, probably because they have not been taught much about the "nature of science" (Norris \& Phillips, 1994; Phillips \& Norris, 1999; Ratcliffe, 1999). Intrinsic to the knowledge of the nature of science is knowledge about the content and structure that feature scientific publications (Korpan et al., 1997), of which the explored 1NA trained students and 2B+3BI-immersed students did not seem to have acquired, substantially.

For exercising pupils' critical thinking skills, the most controversial health issues could be brought to "trail" in the classrooms of both 1NA , 2BI and 3BI. Unfortunately, since 2BI/3BI-teachers and pupils in Norway seem to struggle very hard to accomplish the content-dominated 2BI and 3BI syllabi, they might not have much time left for debating the "flow" of non-scientific health claims in society (BUN, 2004, unpublished results; Sampson, 2001). However, this article results probably justify to put more emphasize on classroom discussions of media health claims at the 
expense of teaching 2BI/3BI-topics that might only have special value for pupils bound for further university studies in biology.

\section{Validity of the study}

Because of relatively few responses from the invited university colleges of nursing, physiotherapy, social educator, and radiography, and the low student response rate, additionally, extensive use of sample statistics has been avoided. The large difference between the numbers of students in the two groups $(\mathrm{N}=327$ for the $1 \mathrm{NA}$ trained students versus $\mathrm{N}=80$ for the $2 \mathrm{BI}+3 \mathrm{BI}$-immersed students) makes probably statistic comparison between the groups questionable. However, Chisquare and Mann-Whitney U-tests were applied to demonstrate "the strength" of differences that might possibly occur between the two groups and items - of which there were not.

Considering that student questionnaires from all the positive responding university colleges were collected, one might speculate that only the students with positive attitudes towards quantitative research (of this kind) have participated in this study. The postal communication of the questionnaire and its considerable length, could possibly also explain the low response rate.

Taken together, generalisation of the student questionnaire results is not appropriate; only some "trends" and "patterns," might also have been demonstrated here. By using the research methodology of this study, and subsequent in-depth interviews, pupils in upper secondary schools' CAMattitudes and critical evaluation skills of health claims should preferably be explored.

\section{Conclusion}

This survey probably demonstrates that the responding health science students' pre-college immersion in the Norwegian upper secondary school biology courses 2BI and 3BI have not contributed to these students' evolvement of scepticism towards CAM, and to the acquirement of scientific evaluation skills of media health claims. For exercising pupils' scientific reasoning abilities and critical thinking skills as ingredients of their science and scientific literacy, critical evaluation of published CAM claims in the media might be a current and relevant approach for teachers to apply in any upper secondary science course.

\section{ACKNOWLEDGEMENT}

The entire research project was financially supported by Akershus University College.

\section{REFERENCES}

Astin, J. (1998). Why patients use alternative medicine: results of a national study. Journal of American Medical Association, 279(19), 1548-1553.

Bauer, H.H. (1994). Scientific literacy and the myth of the scientific method. Urbana, Illinois: University of Illinois Press.

Bell, G. (1998). Hva kan de...og hvor får de det fra? Hovedfagsoppgave i realfagsdidaktikk. Det matematisk-naturvitenskapelige faktultet, Institutt for lærerutdanning og skoleutvikling, University of Oslo (non-English).

Bringle, W., \& Gaskell, P.J. (1994). Scientific Literacy for Decisionmaking and Social Construction of Scientific Knowledge. Science Education, 72(2), 185-201.

BUN (2004). The research project: Biologiutdanning i Norge. Naturfagsenteret, University of Oslo. (unpublished results).

Cassileth, B.R. (1999). Evaluating complementary and alternative therapies for cancer patients. Cancer Journal for Clinicians, 49(6), 362-375. 
Cobern, W., \& Aikenhead, G. (1998). Cultural Aspects of Learning Science. In B.J. Fraser and K.G. Tobin (Eds.), The International Handbook of Science Education. Dordrecht: Kluwer Academic Publishers.

Favero, T. (1998). Double Dipping for Research: An Introduction to the Scientific Method. American Biology Teacher, 60(7), 524-525.

Goode, E. (2002). Education, scientific knowledge, and belief in the paranormal. Skeptical Inquirer, 26, 24-25.

Holton, G. (1992). How to think about the anti-science phenomenon? Public Understanding of Science, 1(1), 103-128.

Kind, P.M. (2003). Praktisk arbeid og naturvitenskapelig allmenndannelse. In B. Bungum, \& D. Jorde, (Eds.), Naturfagdidaktikk. Perspektiver - Forskning - Utvikling (pp. 226-244). Oslo: Gyldendal Akademisk, Norway. (non-English).

Kolstø, S.D. (2001). Scientific literacy for citizenship: Tools for dealing with the science dimension of controversial socio-scientific issues. Science Education, 85(3), 291-310.

Korpan, C.A., Bisanz, G.L., Bisanz, J., \& Henderson, J. (1997). Assessing literacy in science: Evalution of scientific news briefs. Science Education, 81(5), 515-532.

KUF. (1994). Reform '94. Videregående opplæring. Kirke- og undervisningsdepartementet, Oslo, januar, 1994.

Kuhn, D. (2001). How people know? Psychological Science, 12(1), 1-8.

Lederman, N.G. (1992). Students' and teachers' conceptions of the nature of science: a review of the research. Journal of Research in Science Teaching, 29(4), 331-359.

Martin, M. (1994). Pseudoscience, the Paranormal, and Science Education. Science \& Education, 3, 357-371.

Millar, R., \& Driver, R. (1987). Beyond processes. Studies in Science Education, 14, 33-62.

Norris, S.P,. \& Phillips, L.M. (1994). Interpreting pragmatic meaning when reading popular reports of science. Journal of Research in Science Teaching, 31(9), 947-967.

O'Callaghan, F.V., \& Jordan, N. (2003). Postmodern values, attitudes and the use of complementary medicine. Complementary Therapies in Medicine, 11(1), 28-32.

ODIN, (2005a). Forskrift om opptakskrav til grunnutdanninger ved universitet og høgskoler. http://odin.dep.no/ufd/norsk/dok/regelverk/lover/045061-200007/dok-bn.html Accessed: 05/20/05. (non-English).

ODIN, (2005b). Lærerplan for videregående opplæring: Biologi 2BI og Biologi 3BI. http://odin. dep.no/ufd/norsk/tema/utdanning/grunnopplaering/045051-990050/dok-bn.html Accessed: 05/20/05. (non-English).

Pallas, A.M. (2001). Preparing educational doctoral students for epistemology diversity. Educational Researcher, 30(5), 6-11.

Paul, R. (1995). Critical Thinking: How to Prepare Students for a Rapidly Changing World. Santa Rosa: Foundation for Critical Thinking.

Pettersen, S., \& Bye, A. (2005). "If you can't beat them, join them." Nursing education teachers want complementary-alternative medicine to be taught to nursing students, although their attitudes towards it are different. Småskriftserien, 2, Lillestrøm: Akershus University College Press.

Pettersen, S., \& Olsen, R.V. (2005). Exploring predictors of health sciences students' attitudes towards complementary-alternative medicine. (Accepted for publication in Advances in Health Science Education).

Pettersen, S., \& Solberg, J. (2003). Students of Health Sciences' Evaluation of Media reports of Health Research: A Norwegian Study. In J. Lewis, A. Magro, and L. Simonneaux, (Eds.), Biology education for the real world. Student - teacher - citizen (pp. 293-307). ToulouseAuzeville: Enfa.

Pettersen, S. (2004). Exploring the "status"of the biological sciences in Norwegian health sciences. In E.K. Henriksen and M. Ødegaard (Eds.), Naturfagenes didaktikk - en disiplin i forandring? (pp. 93-118). Kristiansand: Høyskoleforlaget. 
Pettersen, S. (2005a). Norwegian health journalists' ability to report on health research: A concern to science education? NorDiNa, 1, 5-16.

Pettersen, S. (2005b). The relevance of teaching about the "nature of science" to students of the health sciences. In K. Boersma, M. Goedhart, O. De Jong, and H. Eijkelhof, (Eds.), Research and the quality of science education. (pp. 269-282). Dordrecht: Springer.

Phillips L.M., \& Norris, S.P. (1999). Interpreting popular reports of science: what happens when reader's world meets the world on paper? International Journal of Science Education, 21(3), 317-327.

Poleszynski, D.V. (1999). Skolemedisin og alternative medisin - konkurranse eller samarbeid. Doktoravhandling for dr. phil.-grad ved Institutt for Sosiologi, Universitetet i Tromsø, Norge. (non-English).

Ratcliffe, M. (1999). Evaluation of abilities in interpreting media reports of scientific research. International Journal of Science Education, 21(10), 1085-1099.

Risberg, T., \& Kolstad, A. (2003). Alternativ medisin - holdninger og bruk blant sykehusansatte leger, sykepleiere og kontorpersonell i Nord-Norge. Tidsskrift for Den Norske Laegeforening, 123, 504-606. (non-English).

Sampson, W. (2001). The Need for Educational Reform in Teaching about Alternative Therapies. Academic Medicine, 76(3), 248-250.

Schwitzer, G., Mudur, G., Henry, D., Wilson, A., Goozner, M., Simbra, M., Sweet, M., \& Baverstock, K.A. (2005). What Are the Roles and Responsibilities of the Media in Disseminating Health Information? PLoS Med 2(7): e215 http://medicine.plosjournals.org/perlserv/ ?request=get-document\&doi=10.1371/journal.pmed.0020215 (Accessed 09/04/05)

Siahpush, M. (1999). Postmodern attitudes about health: a population-based exploratory study. Complementary therapies in medicine, 7(3), 164-169.

Sjøberg, S. (2000). Kjønn og naturvitenskapens "kroppsspråk". http://folk.uio.no/sveinsj/genus. htm (Accessed 09/04/05).

Solberg, J. (2002). "Amerikanske forskere rapporterer"... Helsefagstudenters evne til kritisk vurdering av helseinformasjon i media. Hovedfagsoppgave i Ernæring, helse- og miljøfag, Høgskolen i Akershus, Norge. (non-English).

Studiehåndboka (2004). Studiehåndboka for studieåret 2004 ved Høgskolen i Oslo. (non-English).

Stuessy, C. (1984). Path Analysis: A Model for the Development of Scientific Reasoning Abilities in Adolescents. Journal of Research in Science Teaching, 26(1), 41-53.

Torrens, D. (1999). Individual Differences and the Belief Bias Effect: Mental Models, Logical Necessity, and Abstract Reasoning. Thinking \& Reasoning, 5(1), 1-28.

UFD (2005). Realfag, naturligvis. Strategi for styrking av realfagene 2002-2007. Utdannings- og forskningsdepartementet (non-English).

Watson, G., \& Glaser, E.M. (1980). Watson-Glaser critical thinking appraisal manual. The Psychological Corporation, San Antonio: Harcourt Brace Jovanovich, Inc. 